Short Communication

\title{
ORGANIC NITROGEN IN POTASSIUM CHLORIDE EXTRACTS OF HISTOSOLS IN THE PHILIPPINES
}

\author{
K.L. SAHRAWAT* \\ The International Rice Research Institute, Los Banos, Laguna (Philippines) \\ (Received February 9, 1982; accepted after revision June 17, 1982)
}

\begin{abstract}
Sahrawat, K.L., 1983. Organic nitrogen in potassium chloride extracts of Histosols in the Philippines. Geoderma, 29:77-80.

Analyses of $2 \mathrm{M} \mathrm{KCl}$ extracts of four Histosols (Tropohemists) in aerobic and anaerobic states showed that they contained significant amounts of organic $\mathrm{N}(21-102 \mathrm{mg} \mathrm{N} / \mathrm{kg}$ of soil) but that the amounts were higher in anaerobic samples (following 4 weeks incubation under waterlogged conditions). It is suggested that the amounts of organic $\mathrm{N}$ extracted by $\mathrm{KCl}$ and other salt solutions should be taken into account along with mineral $\mathrm{N}$ estimation to avoid error in measuring potentially mineralizable $\mathrm{N}$ in Histosols of tropical lowlands.
\end{abstract}

\section{INTRODUCTION}

Nitrogen-supplying capacity of wetland rice soils plays a key role in $\mathrm{N}$ nutrition of rice even in well fertilized paddies because about 50 to $75 \%$ of the total $\mathrm{N}$ used by a rice crop comes from the soil mineral $\mathrm{N}$ pool (Broadbent, 1978). The N-supplying capacity of wetland rice soils is usually assessed by measuring $\mathrm{NH}_{4}^{+}$produced in soils under waterlogged conditions during short periods ranging from 6 to 14 days (Chang, 1978, Sahrawat, 1982). The measurement of $\mathrm{NH}_{4}^{+}$in flooded soils is thus an important component of such research programs.

Exchangeable $\mathrm{NH}_{4}^{+}$in soils is usually measured by extracting the samples with $2 M \mathrm{KCl}$ using a soil to $\mathrm{KCl}$ ratio of $1: 10$. The $\mathrm{NH}_{4}^{+}$in the filtered extracts is determined by distilling a suitable aliquot with $\mathrm{MgO}$ (Bremner, 1965b). In an earlier study, we found that direct distillation of samples of aerobic and anaerobic soils used for rice in the Philippines with $\mathrm{MgO}$ gave inflated values for exchangeable $\mathrm{NH}_{4}^{+}$due to hydrolysis of organic $\mathrm{N}$ at high $\mathrm{pH}$ 's (9.9-10.7) due to the boiling of the MgO suspensions (Sahrawat and Ponnamperuma, 1978). Our preliminary observation also indicated that $\mathrm{KCl}$ extracts of some organic soils contained alkali-labile $\mathrm{N}$.

\footnotetext{
*Present address: International Crops Research Institute for the Semi-Arid Tropics (ICRISAT), ICRISAT Patancheru P.O., Andhrapradesh 502324, India.
} 
The objective of work reported here was to estimate the contents of organic $\mathrm{N}$ in $\mathrm{KCl}$ extracts of 4 organic soils in aerobic and anaerobic states in the Philippines.

Apart from a report by Broadbent and Thenabadu (1967) who found that $\mathrm{KCl}$ and $\mathrm{HCl}$ extracts of humic acid preparations from some soils in California contained alkali-labile organic $\mathrm{N}$, little information is available about the amounts of organic $\mathrm{N}$ extracted by salt solutions usually employed for extracting $\mathrm{NH}_{4}^{+}$. However, this is important because organic $\mathrm{N}$ extracted:by salt solutions can cause serious errors in estimation of potentially mineralizable $\mathrm{N}$ in soils.

\section{MATERIALS AND METHODS}

The soil samples were obtained from layers to a depth of $15 \mathrm{~cm}$ in Tropohemists at four locations in the province of Laguna, Philippines (Sahrawat, 1981). Some of their characteristics are given in Table I. Samples were air-dried and crushed to pass through a 2 -mm sieve before use.

\section{TABLE I}

Some characteristics of the Histosols (Tropohemists)

\begin{tabular}{lllll}
\hline Soil & & $\begin{array}{l}\mathrm{pH} \\
\left(1: 2 \mathrm{H}_{2} \mathrm{O}\right)\end{array}$ & $\begin{array}{l}\text { Organic matter } \\
(\%)\end{array}$ & $\begin{array}{l}\text { Total N } \\
(\%)\end{array}$ \\
\cline { 1 - 4 } No. & Location & & & \\
\hline 1 & Morong & 5.65 & 22.0 & 0.65 \\
2 & Calauan & 6.25 & 36.7 & 1.48 \\
3 & Lam Aw & 6.10 & 39.0 & 1.20 \\
4 & Pangil & 5.95 & 42.0 & 1.40 \\
\hline
\end{tabular}

For the analyses reported in Table I, $\mathrm{pH}$ was measured by a glass electrode using a soil: water ratio of $1: 2$, organic $\mathrm{C}$ and total $\mathrm{N}$ determinations were made as described by Walkley and Black (1934), and Bremner (1965a), respectively.

$2 M \mathrm{KCl}$ extracts of aerobic and anaerobic soil samples (after 4 weeks incubation of 10-g samples under waterlogged conditions with $25 \mathrm{ml}$ water at $30^{\circ} \mathrm{C}$ ) were prepared by shaking a 10 -g sample with $2 M \mathrm{KCl}$ for $1 \mathrm{~h}$ in a wristaction shaker, keeping a soil-to-solution ratio of $1: 10$. The suspension was filtered and the extract was analysed for contents of mineral and total $\mathrm{N}$.

For the mineral $\mathrm{N}\left(\mathrm{NH}_{4}^{+}+\mathrm{NO}_{3}^{-}\right)$determination, a $20-\mathrm{ml}$ aliquot from the extract was distilled with $\mathrm{MgO}$ and Devarda's alloy. The ammonia distilled was absorbed in a boric acid-indicator mixture and titrated with $0.04 \mathrm{M}$ $\mathrm{H}_{2} \mathrm{SO}_{4}$ (Bremner, 1965b). Total $\mathrm{N}$ in the extract was determined by transferring a $50 \mathrm{ml}$ aliquot to a $800-\mathrm{ml}$ kjeldahl flask and digesting with concen- 
trated $\mathrm{H}_{2} \mathrm{SO}_{4}$ at low temperature initially to reduce the volume. The digestion was then carried out at high temperature after adding a $\mathrm{K}_{2} \mathrm{SO}_{4}$ and catalyst mixture (Bremner, 1965a). All analyses and experiments reported were done in duplicate.

\section{RESULTS AND DISCUSSION}

It was found that $\mathrm{KCl}$ extracts of the 4 Histosols samples in an aerobic state contained amounts of organic N varying from 21 to $85 \mathrm{mg} / \mathrm{kg}$ of soil (Table II). $\mathrm{KCl}$-extractable organic $\mathrm{N}$ increased in the anaerobic soil samples following their incubation under waterlogged conditions for 4 weeks at $30^{\circ} \mathrm{C}$. Organic $\mathrm{N}$ content in the anaerobic soil samples ranged from 29 to $102 \mathrm{mg} / \mathrm{kg}$ of soil. The mineral $\mathrm{N}$ (mainly $\mathrm{NH}_{4}^{+}$) content of the aerobic soil samples ranged from 58 to $203 \mathrm{mg} / \mathrm{kg}$ of sample and it increased manyfold (221-483 $\mathrm{mg} \mathrm{N} / \mathrm{kg}$ ) in anaerobic soil samples following waterlogged incubation (Table II). These results showed that in general $\mathrm{KCl}$-extractable organic $\mathrm{N}$ content tended to increase following waterlogged incubation. This may be due to the fact that when soils are flooded low molecular weight, organic $\mathrm{N}$ compounds are synthesized (Ponnamperuma, 1972), which are probably extracted by $\mathrm{KCl}$ and are reflected in higher contents of organic $\mathrm{N}$ in the extracts prepared from anaerobic soil samples.

\section{TABLE II}

Amounts ( $\mathrm{mg} / \mathrm{kg}$ of soil sample) of mineral $\mathrm{N}$, total $\mathrm{N}$ and organic $\mathrm{N}$ extracted by $2 \mathrm{M}$ $\mathrm{KCl}$ from samples of four Histosols in the aerobic and anaerobic states

\begin{tabular}{|c|c|c|c|c|c|c|}
\hline \multirow{2}{*}{$\begin{array}{l}\text { Soil } \\
\text { no. }\end{array}$} & \multicolumn{3}{|l|}{ Aerobic } & \multicolumn{3}{|l|}{ Anaerobic } \\
\hline & mineral $\mathrm{N}$ & total $\mathrm{N}$ & organic $\mathrm{N}^{*}$ & mineral $\mathrm{N}$ & total $\mathrm{N}$ & organic $\mathrm{N}$ \\
\hline 1 & 58 & 79 & 21 & 221 & 250 & 29 \\
\hline 2 & 108 & 152 & 44 & 483 & 538 & 55 \\
\hline 3 & 183 & 238 & 55 & 273 & 339 & 66 \\
\hline 4 & 203 & 288 & 85 & 472 & 574 & 102 \\
\hline
\end{tabular}

* Organic $\mathrm{N}=$ Total $\mathrm{N}-$ mineral $\mathrm{N}\left(\mathrm{NH}_{4}^{+}+\mathrm{NO}_{3}^{-}\right)$.

A recent report by Smith et al. (1980) has indicated that significant amounts of organic $\mathrm{N}$ were removed with the mineral soils were incubated under aerobic conditions and the mineral $\mathrm{N}$ was periodically leached with $0.01 M \mathrm{CaCl}_{2}$. These authors concluded that the common methods for aerobic $\mathrm{N}$ mineralization resulted in leaching and removal of significant amounts of organic N (13-163\% of total mineralized $N$ ) and suggested that the amounts of organic $\mathrm{N}$ leached should be considered in order to avoid serious errors in the determination of $\mathrm{N}$-mineralization potentials and mineralization rate constants for aerobically incubated samples. The 
results of the present study provide further evidence that significant amounts of organic $\mathrm{N}$ are extracted by $2 M \mathrm{KCl}$ from samples of aerobic and anaerobic Histosols, the amounts being higher in samples from anaerobic soils. It is recommended that amounts of organic $\mathrm{N}$ extracted by $\mathrm{KCl}$ should be taken into account along with mineral $\mathrm{N}$ measurements to avoid errors in measuring potentially mineralizable $\mathrm{N}$ in Histosols of tropical lowlands.

\section{ACKNOWLEDGEMENTS}

I thank the International Rice Research Institute (IRRI), Los Baños, Laguna, Philippines for financial support and Dr. F.N. Ponnamperuma, Principal Soil Chemist, for his interest in the work.

\section{REFERENCES}

Bremner, J.M., 1965a. Total nitrogen. In: C.A. Black (Editor), Agronomy 9, Methods of Soil Analysis. Am. Soc. Agron., Madison, Wisc., pp. 1149-1178.

Bremner, J.M., 1965b. Inorganic forms of nitrogen. In: C.A. Black (Editor), Agronomy 9, Methods of Soil Analysis. Am. Soc. Agron., Madison, Wisc., pp. 1179-1237.

Broadbent, F.E., 1978. Transformations of soil nitrogen. In: Nitrogen and Rice. Int. Rice Res. Inst., Los Baños, Laguna, pp. 105-118.

Broadbent, F.E. and Thenabadu, M.W., 1967. Extraction of ammonia fixed by soil organic matter. Soil Sci., 104: 283-288.

Chang, S.C., 1978. Evaluation of the fertility of rice soils. In: Soils and Rice. Res. Int. Rice Inst., Los Baños, Laguna, pp. 521-541.

Ponnamperuma, F.N., 1972. The chemistry of submerged soils. Adv. Agron., 24: 29-96.

Sahrawat, K.L., 1981. Ammonification in air-dried tropical lowland Histosols. Soil Biol. Biochem., 13: 323-324.

Sahrawat, K.L., 1982. Assay of nitrogen supplying capacity of tropical rice soils. Plant Soil, 65: 111-121.

Sahrawat, K.L. and Ponnamperuma, F.N., 1978. Measurement of exchangeable $\mathrm{NH}_{4}^{+}$in tropical rice soils. Soil Sci. Soc. Am. J., 42: 282-283.

Smith, J.L., Schnabel, R.R., McNeal, B.L. and Campbell, G.S., 1980. Potential errors in the first-order model for estimating soil nitrogen mineralization potentials. Soil Sci. Soc. Am. J., 44: 996-1000.

Walkley, A. and Black, I.A., 1934. An examination of the Degtjareff method for determining soil organic matter and a proposed modification of the chromic acid titration method. Soil Sci., 37: 29-38. 